Article

\title{
Sensory and Biological Potential of Encapsulated Common Bean Protein Hydrolysates Incorporated in a Greek-Style Yogurt Matrix
}

\author{
Samantha Free-Manjarrez, Luis Mojica (D), Hugo Espinosa-Andrews (D) and Norma Morales-Hernández *(iD
}

Citation: Free-Manjarrez, S.; Mojica, L.; Espinosa-Andrews, H.;

Morales-Hernández, N. Sensory and Biological Potential of Encapsulated Common Bean Protein Hydrolysates Incorporated in a Greek-Style Yogurt Matrix. Polymers 2022, 14, 854.

https://doi.org/10.3390/

polym14050854

Academic Editors: Juan

Arturo Ragazzo-Sánchez and

Montserrat Calderón-Santoyo

Received: 20 January 2022

Accepted: 15 February 2022

Published: 22 February 2022

Publisher's Note: MDPI stays neutral with regard to jurisdictional claims in published maps and institutional affiliations.

Copyright: (C) 2022 by the authors. Licensee MDPI, Basel, Switzerland. This article is an open access article distributed under the terms and conditions of the Creative Commons Attribution (CC BY) license (https:// creativecommons.org/licenses/by/ $4.0 /)$.
Tecnología Alimentaria, Centro de Investigación y Asistencia en Tecnología y Diseño del Estado de Jalisco, A. C., CIATEJ, Unidad Zapopan, Camino Arenero 1227, El Bajío, Zapopan 45019, Mexico; jfree@ciatej.mx (S.F.-M.); lmojica@ciatej.mx (L.M.); hespinosa@ciatej.mx (H.E.-A.)

* Correspondence: nmorales@ciatej.mx; Tel.: +52-(33)-3345-5200

\begin{abstract}
The work aimed to develop a gel as a protective barrier of common bean protein hydrolysates to be incorporated into a Greek-style yogurt and evaluate the sensory perception and biological potential. The gel was formed by complex coacervation and induced heat at a $\mathrm{pH} 3.5$ and 3:1 biopolymer ratio (whey protein and gum arabic). The gel presented a $39.33 \%$ yield, low syneresis $(0.37 \%)$, and a gel strength of $100 \mathrm{~g}_{f}$. The rheological properties showed an elastic behavior $\left(\mathrm{G}^{\prime}>\mathrm{G}^{\prime \prime}\right)$. The gel with the most stable characteristics favored the incorporation of $2.3 \mathrm{~g}$ of hydrolysates to be added into the Greek-style yogurt. Nutritionally, the Greek-style yogurt with the encapsulated hydrolysates presented $9.96 \%$ protein, $2.27 \%$ fat, and $1.76 \%$ carbohydrate. Syneresis $(4.64 \%)$, titratable acidity $(1.39 \%)$, and viscoelastic behavior presented similar characteristics to the Greek-style control yogurt. The bitterness and astringency in yogurt with encapsulated hydrolysates decreased $44 \%$ and $52 \%$, respectively, compared to the yogurt control with the unencapsulated hydrolysates. The Greek-style yogurt with the encapsulated hydrolysates showed the ability to inhibit enzymes related to carbohydrate metabolism ( $\alpha$-amylase (92.47\%) and dipeptidyl peptidase-4 (75.24\%) after simulated gastrointestinal digestion). The use of gels could be an alternative to transporting, delivering, and masking off-flavors of common bean protein hydrolysates in food matrices to decrease glucose absorption for type 2 diabetes patients.
\end{abstract}

Keywords: gel; common bean protein hydrolysates; Greek-style yogurt; complex coacervation; functional food

\section{Introduction}

Functional foods have attracted the interest of the food industry and consumers due to their essential role in preventing non-communicable diseases [1-3]. The growing demand can be explained by the rising cost of medical care, increased life expectancy, and increased consumer interest in obtaining health benefits [1]. There is a wide variety of bioactive compounds obtained from natural sources, such as pulses, plants, fruits, or vegetables, that show beneficial effects on human health and are used in the formulation of functional foods [4,5]. Common beans have been considered a functional food due to their content of polyphenols, resistant starch, oligosaccharides, saponins, phytosterols, proteins, and bioactive peptides [6,7]. Several authors have reported that common bean protein hydrolysates could play an essential role in controlling or preventing type 2 diabetes mellitus through in vitro assays [8-10] as in vivo [11]. Despite the health benefits, as the protein hydrolyzes, it provides a bitter or astringent taste in foods [12,13]. Furthermore, these compounds could react and interact with other components during food processing and storage, changing their composition and potential health benefits. Therefore, encapsulation is an important technology for the stability of bioactive peptides in the development of functional foods. In addition to keeping their functionality stable, it can protect by reducing unpleasant notes 
such as bitterness and astringency when consumed [2,13-16]. Encapsulation consists of coating solids, liquids, or gases with different materials to release the bioactive compounds at different intervals, limiting unwanted reactions and improving the stability, bioavailability, and organoleptic properties of these compounds [13,17,18]. The choice of the most suitable encapsulation method depends on the type of core material and the final product characteristics where the encapsulated will be applied [19]. An encapsulation alternative is a gel; its properties can be manipulated to develop a food grade system for encapsulating bioactive ingredients, improving their stability and delivery. A gel is an intermediate between a solid and liquid with flow and elastic characteristics. It also contains water in its network of cross-linked biopolymer molecules [20,21]. Moreover, the gels can act as texture modifiers and fat or starch replacers to reduce calories in foods [22]. Complex coacervation is a spontaneous phase separation of two oppositely charged biopolymers mixed in specific concentration, $\mathrm{pH}$, temperature, and ionic strength conditions [23]. The complex coacervates with encapsulated bioactives, and can be subsequently embedded in a gel by heat treatment to improve the stability of the enclosed bioactives [24]. Recent research demonstrated that the encapsulation of peptides is an alternative to stabilize and preserve the biological potential of bioactive compounds and improve food acceptance [25-28]. A mussel protein hydrolysate was developed using spray drying with maltodextrin and modified starch in instant noodles. The encapsulation masks the bitterness attributed to the hydrophobic amino acids released in the protein hydrolysis [29]. Casein hydrolysates were encapsulated by complex coacervation using a soy protein isolate and pectin; the bitter taste and stability were improved by encapsulation [30].

A healthy diet can prevent or control type 2 diabetes, improving blood glucose and lipid control [31]. The American Diabetes Association recommends eating low-fat, lowsugar, and low-salt foods, including Greek-style yogurt [32]. Greek-style yogurt is currently the fastest-growing product in the dairy industry and is obtained after draining whey. Its consumption is directly related to health benefits associated with its higher nutritional value, especially its high protein content [33-35].

Therefore, the aims of this work were: (1) to generate a gel as a protective barrier for common bean protein hydrolysates from a whey protein concentrate and gum arabic by complex coacervation; (2) to incorporate the gel with common bean protein hydrolysates into a Greek-style-yogurt; and (3) evaluate the sensory perception (bitterness and astringency) and biological potential of Greek-style yogurt with common bean protein hydrolysates.

\section{Materials and Methods}

\subsection{Materials}

Raw black bean (Phaseolus vulgaris L.) San Luis cultivar (2017) from Sombrerete, Zacatecas, Mexico $\left(23^{\circ} 37^{\prime} 53.9^{\prime \prime} \mathrm{N} 103^{\circ} 38^{\prime} 29.5^{\prime \prime} \mathrm{W}\right)$. The dry beans were stored at $4^{\circ} \mathrm{C}$ until use. Pepsin from porcine gastric mucosa (EC 232-629-3), pancreatin from porcine pancreas (EC 232-468-9), $\alpha$-Amylase from porcine pancreas (EC 232-565-6), quinine monohydrochloride dihydrate (90\%), and tannic acid were purchased from Sigma-Aldrich (St. Louis, MO, USA). DPP-IV Glo ${ }^{\circledR}$ protease assay was purchased from Promega (Madison, WI, USA). Gum arabic (GA; Acacia senegal) was purchased from Reasol (Mexico City, Mexico) (2.3\% protein, $3.7 \%$ ash content, $0.1 \%$ fat, and $93.8 \%$ carbohydrates content). Whey protein concentrate (WPC) was purchased from Hilmar (Vilher, Jalisco, Mexico) $(84.1 \%$ protein, 5.1\% ash content, $0.7 \%$ fat, and $10.0 \%$ carbohydrates content). Canola oil was purchased from a local market (Jalisco, Mexico). Culture YO-PROX 753 was purchased from Bioprox (Mexico City, Mexico). All other reagents were analytical grade.

\subsection{Gel (W-GEL) Preparation}

Biopolymers (WPC and GA) were dispersed in deionized water, and the solutions were stored for the night at $4{ }^{\circ} \mathrm{C}$ to ensure complete hydration. Both biopolymer solutions were adjusted at $\mathrm{pH}$ 3.5. The coarse emulsion was obtained, mixing GA with canola oil 
(ratio 2:1) using a high-shear disperser at 9,500 rpm for 5 min (Ultra-Turrax T25, IKA Works, Inc., Wilmington, NC, USA). The emulsion size was reduced (500-600 nm) using an ultrasonic processor (Model CL-18, serial no. 2012030312), applying 50\% of amplitude for $15 \mathrm{~min}$. A portion of the prepared emulsion was mixed with WPC at two concentrations (5\% and $7.5 \%$ ) of total solids and two ratios of WPC:GA (5:1 and 3:1) to form the complex coacervates. The four mixtures were left to rest at $50{ }^{\circ} \mathrm{C}$ for $2 \mathrm{~h}$. Then, the samples were centrifuged at $1000 \times g$ for $15 \mathrm{~min}$. The supernatants were removed, and the sediments were heated at $85{ }^{\circ} \mathrm{C}$ for $30 \mathrm{~min}$ and cooled at $4{ }^{\circ} \mathrm{C}$ [36]. Four different W-GELs were formed and refrigerated at $4^{\circ} \mathrm{C}$ for $24 \mathrm{~h}$ and subsequently characterized.

\subsection{W-GEL Physicochemical Characterization}

\subsubsection{Yield (\%)}

The yield of the W-GEL was determined using the following equation of RodríguezRodríguez et al. [37]:

$$
\text { Yield }(\%)=\left(\left(\mathrm{m}_{\mathrm{O}}-\mathrm{m}_{\mathrm{i}}\right) / \mathrm{m}_{\mathrm{o}}\right) \times 100
$$

where $m_{0}$ is the initial mass used to produce the W-GEL, and $m_{i}$ is the dried W-GEL mass.

\subsubsection{Gel Strength (Firmness)}

The W-GEL strength was performed using a Texturometer TA XT PLUS (Godalming, Surrey GU7 1YL, UK) by a method reported by Qin et al. [38] with some modifications. The W-GEL was compressed using a $25 \%$ deformation to obtain the gel strength using a cylindrical probe (P/0.5R). The EXPONENT Stable Micro Systems version 6.1.16.0 software was used to calculate gel strength.

\subsubsection{Syneresis}

Syneresis was measured under a method reported by Banerjee and Bhattacharya [39]. The W-GEL was centrifuged in $50 \mathrm{~mL}$ graduated tubes at $890 \times g$ for $15 \mathrm{~min}$. Then, the supernatant was separated and weighed. The syneresis was calculated in percentage with the following formula:

$$
\text { Syneresis }(\%)=\left(\left(m_{1}-m_{2}\right) / m_{1}\right) \times 100
$$

where $m_{1}$ is the initial weight of the W-GEL and $m_{2}$ is the final weight of the sample after removing the supernatant.

\subsubsection{Rheological Measurement}

The measurements of the viscoelastic properties of the W-GEL were carried out according to a methodology reported by Li et al. [40], using stress control rheometer equipment (AR1000, TA Instrument, New Castle, DE, USA) with a cross-hatched geometry (40 mm diameter) and a gap of $1000 \mu \mathrm{m}$ at $4{ }^{\circ} \mathrm{C}$. An amplitude strain sweep $(0.1-100 \%)$ was performed using $1 \mathrm{rad} / \mathrm{s}$ to find the viscoelastic linear region. Subsequently, a frequency sweep was performed at $0.5 \%$ strain, varying from 0.1 to $100 \mathrm{~Hz}$. In addition, a dynamic stress sweep test was performed to find the yield stress of emulsion gels using oscillatory stress from 1000 to $4000 \mathrm{~Pa}$ and $0.5 \%$ strain at $4{ }^{\circ} \mathrm{C}$.

\subsection{Application of the W-GEL with BPH in a Greek-Style Yogurt}

2.4.1. Common Bean Protein Hydrolysates (BPH)

Common bean protein hydrolysates were obtained following the procedure proposed by Mojica et al. [11]. The enzymatic hydrolysis was carried out with alcalase/substrate 1:20 $(w / w)$ and $\mathrm{pH} 7.0$ at $50{ }^{\circ} \mathrm{C}$ for $2 \mathrm{~h}$. Then, the $\mathrm{BPH}$ was lyophilized. 


\subsubsection{Preparation of W-GEL with BPH (BPH-GEL)}

The methodology was followed as in Section 2.2. A total of $2.3 \mathrm{~g}$ of BPH was initially dispersed in the canola oil and GA to continue the gel formation, and then was incorporated in a serving of Greek-style yogurt (125 g).

\subsubsection{Greek-Style Yogurt Preparation}

Low-fat milk $(10 \mathrm{~g} / \mathrm{L})$ was heated to $92 \pm 1{ }^{\circ} \mathrm{C}$ for $3 \mathrm{~min}$ and subsequently cooled to $43 \pm 1^{\circ} \mathrm{C}$ in an ice bath. Greek-style yogurt was produced by inoculating the YO-PROX 753 culture and incubating at $43 \pm 1{ }^{\circ} \mathrm{C}$ for $4 \mathrm{~h}$. Then it was cooled to $4 \pm 1{ }^{\circ} \mathrm{C}$ and kept there for $18 \mathrm{~h}$. After refrigeration, Greek-style yogurt was drained for $18 \mathrm{~h}$. BPH-GEL was incorporated into the yogurt and mixed gently for its total integration (BPH-GEL-yogurt) at the end. Greek-style yogurt without gel, BPH (control yogurt), and Greek-style yogurt with unencapsulated BPH (BPH-Ue-yogurt) were made for physicochemical and sensory comparison. The products obtained were packaged and stored at $6 \pm 1{ }^{\circ} \mathrm{C}$ for 3 days before analysis [41].

\subsection{Characterization of BPH-GEL-Yogurt and Control Yogurt}

\subsubsection{Syneresis}

A portion (10 g) of yogurt was centrifuged at $1000 \times g$ for $10 \mathrm{~min}$. The supernatant was separated and weighed, and the syneresis was expressed as a percentage by weight compared to the initial weight of the yogurt [41].

\subsubsection{Titratable Acidity}

Yogurt variations were analyzed by titratable acidity and expressed in lactic acid percentage. A portion (18 g) of yogurt was diluted in distilled water (1:2). Phenolphthalein $(0.5 \mathrm{~mL})$ was added, and then yogurts were titrated with $0.1 \mathrm{~N} \mathrm{NaOH}$ until a permanent pink color appeared for at least $30 \mathrm{~s}$ [42].

\subsubsection{Rheological Measurement}

Rheological properties were determined according to a method reported by CrispínIsidro et al. [41]. A rheometer equipped (AR1000, TA Instrument, New Castle, DE, USA) with a cross-hatched geometry (40 mm diameter) with a gap of $1000 \mu \mathrm{m}$ at $4{ }^{\circ} \mathrm{C}$ was used. Amplitude sweeps (0.01 to $100 \%$ deformation, $1 \mathrm{~Hz})$ were carried out in both yogurts. Before measuring, yogurts were standing for $30 \mathrm{~min}$ to recover the structure and equilibrate the temperature at $4{ }^{\circ} \mathrm{C}$.

\subsubsection{Confocal Microscopy of BPH-GEL and BPH-GEL-Yogurt}

Microstructures were evaluated according to the method described by Schmitt et al. [43]. The WPC was labeled with fluorescein isothiocyanate (FITC). BPH was labeled with rhodamine isothiocyanate (RBITC). Once marked, the BPH-GEL was formed. A confocal microscopy DMRA2 (Leica Microsystems GmbH, Wetzlar, Germany) was used with two lasers at 458 and $532 \mathrm{~nm}$ excitation, with a detection window between 492 and $520 \mathrm{~nm}$ and 590 and $690 \mathrm{~nm}$, respectively. Images were captured and managed using LAS X software (Leica Microsystems). Samples were observed with a $40 \times$ objective magnification and Leica immersion oil type F solution.

\subsection{Sensory Evaluation of BPH-GEL-Yogurt and BPH-Ue-Yogurt}

Sensory evaluation was carried out by ten trained judges (20-48 years old) who completed the training according to ISO 8586-2 [44]. An unstructured scale was used to determine the degree of bitterness and astringency of BPH-GEL-yogurt and BPH-Ueyogurt, using quinine $(0.015,0.021$ y $0.027 \mathrm{~g} / \mathrm{L})$ and tannic acid $(0.2,0.37 \mathrm{y} 0.48 \mathrm{~g} / \mathrm{L})$ as references, respectively. The quantitative perception of bitterness and astringency attributes were determined for each sample. 


\subsection{Biological Potential of BPH-GEL-Yogurt and Control Yogurt}

\subsubsection{Gastrointestinal Digestion In Vitro}

The release of bioactive compounds was measured and simulated in vitro gastrointestinal conditions described by Sanguansri et al. [45]. Simulated gastric fluid (SGF) was prepared by dissolving pepsin $(3.2 \mathrm{~g} / \mathrm{L})$ in sodium chloride $(2.0 \mathrm{~g} / \mathrm{L})$ solution. The $\mathrm{pH}$ was adjusted to 2.0 with $2 \mathrm{~N} \mathrm{HCl}$. Simulated intestinal fluid (SIF) was prepared by dissolving pancreatin $(10.0 \mathrm{~g} / \mathrm{L})$ in a monobasic potassium phosphate $(6.8 \mathrm{~g} / \mathrm{L})$ solution. Subsequently, the $\mathrm{pH}$ was adjusted to 6.8 with $2 \mathrm{~N} \mathrm{NaOH}$.

BPH-GEL-yogurt and control yogurt were dispersed in SGF $(10 \mathrm{~mL})$ and incubated in a water bath for $2 \mathrm{~h}$ at $37^{\circ} \mathrm{C} / 100 \mathrm{rpm}$ (Boekel Scientific, Feasterville, PA, USA). Subsequently, the $\mathrm{pH}$ was adjusted to 6.8 using $1 \mathrm{M} \mathrm{NaOH}$, and then SIF $(10 \mathrm{~mL})$ was added. The digestion was continued for three hours. Samples were taken at the end of the gastric and intestinal simulations. Samples were inactivated with hot water at $90{ }^{\circ} \mathrm{C}$ for $10 \mathrm{~min}$ and were finally dried (spray dryer) to carry out the corresponding tests.

\subsection{2. $\alpha$-Amylase Inhibition Assay}

An $\alpha$-amylase inhibition assay was performed using a modified protocol by Kusano et al. [46]. The undigested starch was detected at $630 \mathrm{~nm}$ (blue, starch-iodine complex). Acarbose was used as a positive control. Percentage of inhibition was calculated using the formula:

$$
\% \operatorname{In}=\left(1-\left[A_{2}-A_{1} / A_{4}-A_{3}\right]\right) \times 100 \%
$$

where $A_{1}$ is the absorbance of the incubated mixture containing hydrolysates sample, starch, and amylase, $A_{2}$ is the absorbance of the incubated mixture of sample and starch, $A_{3}$ is the absorbance of the incubated mixture starch and amylase, $A_{4}$ is the absorbance of the incubated solution containing starch.

\subsubsection{DPP-IV Inhibition}

A DPP-IV inhibition assay was performed using a method described by Hsieh-Lo et al. [47]. Luminescence was measured using a SpectraMax ${ }^{\circledR}$ i3 Multi-Mode Detection Platform (Molecular Devices, Sunnyvale, CA, USA). The inhibition was calculated from the blank and enzyme control for each sample.

\subsection{Statistical Analysis}

All analyses were performed in triplicate. Data are expressed as the mean \pm standard deviation. One-way analysis of variance (ANOVA) was performed using Statgraphics Centurion XVI 16.1.03 statistical software (StatPoint Technologies, Inc., Warrenton, VA, USA). Tukey test was performed to identify significant differences among treatments $p<0.05$.

\section{Results and Discussion}

\subsection{Physicochemical Properties of W-GEL}

Four gels (W-GEL 1 to W-GEL 4) were formed by complex coacervation followed by induced heating, the combination of two WPC:GA ratios (5:1 and 3:1), and two final total solids concentrations ( 5 and $7.5 \%)$. No significant differences $(p>0.05)$ were observed among the yield of the W-GELs for treatments (Table 1). The firmness of a sample commonly used to describe the texture of food is associated with gel strength [48]. Treatments with a lower biopolymer concentration (5\%) presented a higher gel strength, such as W-GEL 3 , which presented the highest firmness with a value of $159 g_{f} \pm 8$ in contrast to gels with higher biopolymer concentrations $(7.5 \%)$, due to the relationship with the percentage of water retention. A high water loss produces firmer gel structures; on the contrary, less water release generates softer gels due to the amount of water entrapped in the gel network [49]. W-GEL textural properties can be associated with water retention capacity and the microstructure. 
Table 1. Interrelation between yield, gel strength, syneresis, and rheology of W-GEL.

\begin{tabular}{cccccccc}
\hline \multirow{2}{*}{ Tx. } & Concentration & Ration. & Yield & Gel Strength & Syneresis & \multicolumn{2}{c}{ Rheology G'(Pa) } \\
\cline { 2 - 7 } & $\mathbf{( \% )}$ & $\mathbf{( W P C - G A )}$ & $\mathbf{( \% )}$ & $\mathbf{( g f )}$ & $\mathbf{( \% )}$ & u (0.1) & u (100) \\
\hline W-GEL 1 & 7.5 & $5: 1$ & $36.56 \pm 1.17^{\mathrm{a}}$ & $55 \pm 2^{\mathrm{a}}$ & $4.20 \pm 0.05^{\mathrm{a}}$ & $5722^{\mathrm{a}}$ & $13,490^{\mathrm{a}}$ \\
W-GEL 2 & 7.5 & $3: 1$ & $35.78 \pm 1.35^{\mathrm{a}}$ & $96 \pm 5^{\mathrm{b}}$ & $2.71 \pm 0.25^{\mathrm{b}}$ & $3753^{\mathrm{b}}$ & $9044^{\mathrm{b}}$ \\
W-GEL3 & 5.0 & $5: 1$ & $35.33 \pm 1.89^{\mathrm{a}}$ & $159 \pm 8^{\mathrm{c}}$ & $3.89 \pm 0.62^{\mathrm{a}}$ & $5473^{\mathrm{a}}$ & $13,680^{\mathrm{a}}$ \\
W-GEL 4 & 5.0 & $3: 1$ & $39.33 \pm 1.76^{\mathrm{a}}$ & $100 \pm 2^{\mathrm{b}}$ & $0.37 \pm 0.25^{\mathrm{c}}$ & $5508^{\mathrm{a}}$ & $13,730^{\mathrm{a}}$ \\
\hline
\end{tabular}

Tx: Treatment. W-GEL: WPC:GA gel without BPH. Values are the mean of three replicates \pm standard deviation Lower case letters mean significantly different by column. $(p<0.05)$.

Syneresis is a natural phenomenon during which excess unbound water leaves the gel. This undesirable phenomenon can be reduced by selecting the appropriate biopolymer at a suitable final concentration, ratio, and $\mathrm{pH}$ [39]. The syneresis percentage ranged from 0.37 to $4.20 \%$. W-GEL 1, W-GEL 2, and W-GEL 3 achieved the highest syneresis percentage. However, in W-GEL 4 significant differences $(p<0.05)$ were observed compared to the other treatments. Biopolymer content can influence the gel matrix's syneresis, increasing the syneresis percentage values during storage $[39,50]$. This behavior was related to the ability of biopolymers, mainly proteins, to capture water, allowing the formation of a viscoelastic network with good water retention and increasing volume [39].

The linear viscoelastic region was observed at a strain of $1 \%$ for all samples, and a constant strain of $0.5 \%$ was chosen to carry out the frequency sweeps. All the W-GELs exhibited a predominantly solid viscoelastic behavior, since the elastic modulus $\left(G^{\prime}\right)$ was higher than the viscous modulus $\left(G^{\prime \prime}\right)$ in the entire frequency range studied. Table 1 shows the rheological modulus $\mathrm{G}^{\prime}$ variation at low $(0.1 \mathrm{~Hz})$ and high $(100 \mathrm{~Hz})$ frequencies. The results showed that the elastic modulus remained constant at low and high frequencies, the typical behavior of a strong gel. The viscoelastic properties were significantly higher for W-GEL 1, W-GEL 3, and W-GEL 4 compared to W-GEL 2. This behavior has been related to the degree of ionization between both macromolecules, which move away from their stoichiometric relationship and cause a decrease in gel performance [51,52]. However, no significant differences $(p>0.05)$ were observed between W-GEL 1, W-GEL 3 , and W-GEL 4; however, W-Gel 4 presented the lowest syneresis. For application in yogurt, W-GEL 4 was considered suitable for incorporating a dose of $2.3 \mathrm{~g}$ of BPH in $125 \mathrm{~g}$ of Greek-style yogurt; in addition, the proximal composition of W-GEL4 was $11.63 \%$ protein, $5.32 \%$ fat, $10.82 \%$ carbohydrates, and $0.24 \%$ minerals, its consistency favors its incorporation, and its low syneresis could have more stability during storage. Several applications of encapsulation by complex coacervation have favored the stability and perception of bioactive compounds in the development of functional foods [2,13]. Examples include orange essential oil [53] and terpenes in black pepper essential oil [54], in both cases improving their stability. The combination of biopolymers can be more efficient to encapsulate bioactive peptides or hydrolysates to mask bitter flavors and improve their stability and bioavailability [18]. Examples include gelatin-pectin to encapsulate lycopene [28] or chitosan-pectin and chitosan-xanthan gum to palm oil as wall materials for application in food systems in yogurt [55].

\subsection{Application of the W-GEL with BPH in a Greek-Style Yogurt}

\subsubsection{Characterization of BPH-GEL-Yogurt and Control Yogurt}

The bromatological composition of the BPH-GEL-yogurt and the control yogurt are shown in Figure 1. The fat content was significantly higher in the BPH-Gel-yogurt than in the control yogurt $(2.27 \pm 0.02$ vs. $1.97 \% \pm 0.06$ respectively; $p<0.05)$. This behavior was due to the addition of the BPH in the gel to retain more fat. The fat content in both products was lower compared with other studies that report a fat content above $6.4 \%$ (Costa et al. [56]) and 7.0\% (Pinto et al. [57]) in natural Greek-style yogurt. Fat content is 
an important indicator of sensory attributes that impact the characteristics of this type of yogurt, such as consistency and the creaminess sensation [35,58,59].

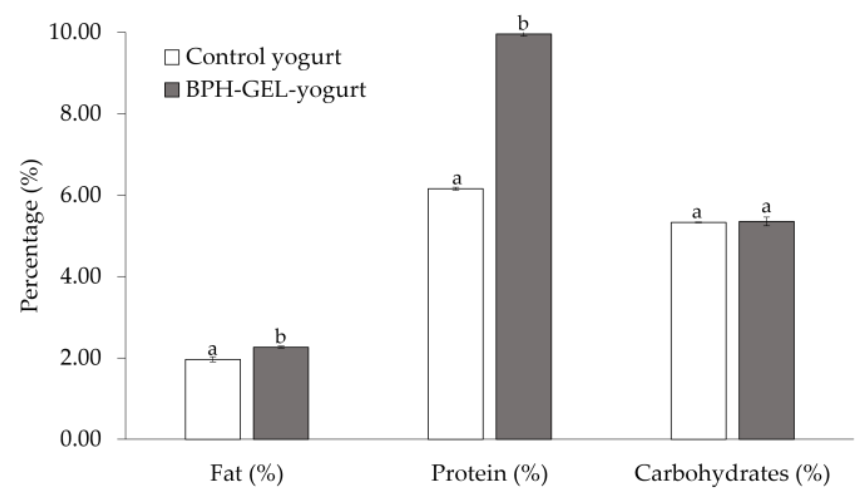

Figure 1. Bromatological composition of control yogurt and BPH-GEL-yogurt. BPH-GEL-yogurt: Greek-style yogurt with BPH encapsulated in a gel; control yogurt: Greek-style yogurt without gel and BPH. Values are the mean of two replicates \pm standard deviation. Lowercase letters mean significantly different by parameter. $(p<0.05)$.

Greek-style yogurt is mainly characterized by its high protein content, having double or triple the amount of protein compared to stirred yogurt $[33,60,61]$. The protein content in the BPH-GEL-yogurt significantly increased $(p<0.05)$ compared with the control yogurt. The protein increase was about 57\% in the BPH-GEL-yogurt, due to the incorporation of $\mathrm{BPH}$ and WPC in the gel as an encapsulation system. A stirred yogurt protein is around $3.1 \%$ [62]. Considering that a Greek-style yogurt contains twice the protein, the results showed that the BPH-GEL-yogurt and control yogurt were within the standards. No significant differences $(p>0.05)$ were observed in carbohydrate content between the $\mathrm{BPH}$ GEL-yogurt and control yogurt. The carbohydrate content in both yogurts is associated with the presence of lactose. The content was low because during whey drain lactose passes freely through the yogurt retention membrane, in addition to the fact that part of the lactose was metabolized during fermentation [59].

Significant differences $(p<0.05)$ were observed among the two yogurts in terms of syneresis (Figure 2). Syneresis was two-fold higher in the control yogurt $(7.27 \% \pm 0.13)$ than the BPH-GEL-yogurt $(4.64 \% \pm 0.88)$. This behavior was attributed to the BPH-GEL incorporation. The increase of proteins in the gel, attributable to WPC and BPH, played an essential role in the water-holding capacity, providing stability to the formed network $[33,41]$.

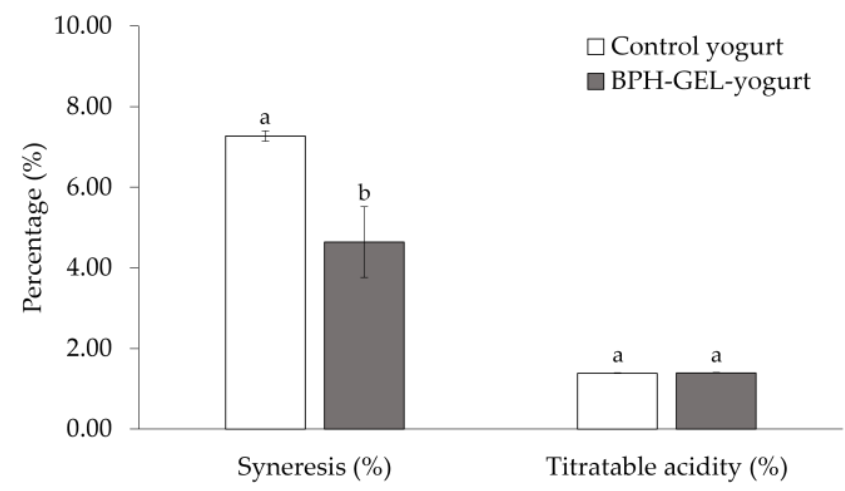

Figure 2. Physicochemical analysis of control yogurt and BPH-GEL-yogurt. BPH-GEL-yogurt: Greekstyle yogurt with BPH encapsulated in a gel; control yogurt: Greek-style yogurt without gel and BPH. Values are the mean of three replicates \pm standard deviation. Lowercase letters mean significantly different by parameter. $(p<0.05)$. 
Titratable acidity measures proteins and phosphates concentration in milk as a good hygienic-sanitary quality [63]. After the three days of processing, there was no significant difference between acidity values in the BPH-GEL-yogurt and control yogurt $(1.40 \pm 0.01$ vs. $1.39 \% \pm 0.01 ; p=0.29)$. A similar acidity behavior was reported with the addition of other ingredients such as inulin [64] or agave fructans [41] in low-fat yogurt.

Rheological measurements are considered the response at the macroscopic level of the properties at the microscopic level of food [65]. The rheological properties of yogurts are shown in Figure 3. All samples showed a predominantly elastic character over viscous behaviors $\left(G^{\prime}>G^{\prime \prime}\right)$, indicating that non-relaxing protein bonds dominated over weak bonds that break and reform rapidly. The higher amount of non-relaxing protein bonds forms a much denser and stronger gel structure [59]. Protein-enriched yogurts ( $\geq 8 \%)$ have been reported to have a firmer texture [34]. This behavior is characteristic of a weak gel exhibiting thinning behavior, characterized by a linear viscoelastic region where $G^{\prime}$ and $G^{\prime \prime}$ showed a constant value of a small percentage of deformation. This is followed by a linear nonviscoelastic region with a downward inflection of the moduli at higher strain values [41] The rheological properties of yogurt were affected by the protein present in the matrix and the process of yogurt manufacture $[34,41,66]$. Both yogurts had a similar consistency. BPH-GEL-yogurt was not affected in texture and acidity characteristics with the addition of BPH-GEL. The structure and texture of the BPH-GEL-yogurt were favored by the increased protein content, showing good water retention in contrast to the control yogurt.

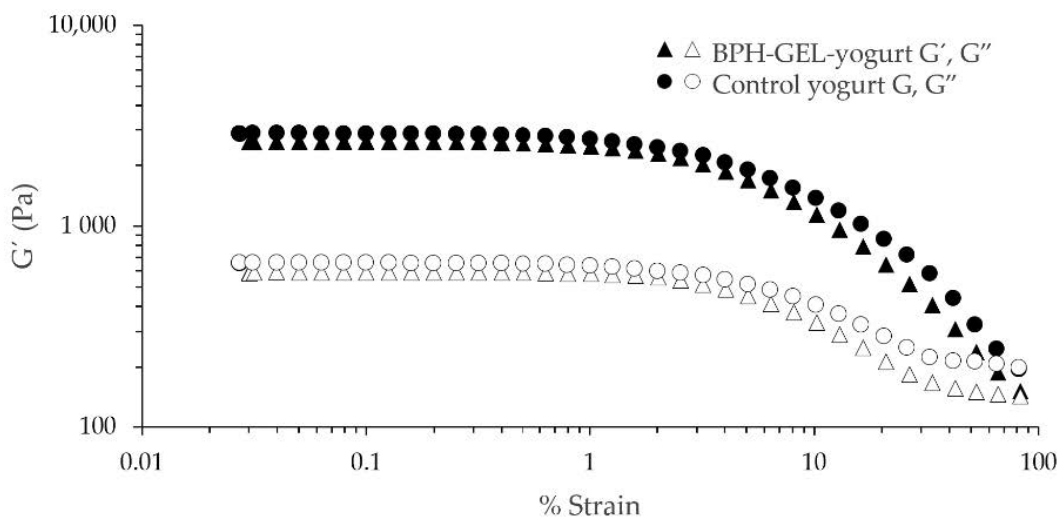

Figure 3. Rheological properties of control yogurt and BPH-GEL-yogurt. The evaluation was made in function of $G^{\prime}$ and G". BPH-GEL-yogurt: Greek-style yogurt with BPH encapsulated in a gel; control yogurt: Greek-style yogurt without gel and BPH.

\subsubsection{Confocal Microscopy of BPH-GEL and BPH-GEL-Yogurt}

The morphological characterization of the BPH-GEL and BPH-GEL-yogurt was performed by confocal microscopy. The identification of the BPH distributed in the gel is shown in Figure 4a,b. Figure 4 a shows a cross-section of a fragment of the BPH-GEL, where the BPH (yellow color) is observed immersed in a W-GEL (blue color). The aggregates formed from the BPH-GEL are shown in Figure $4 \mathrm{~b}$. The microstructure of the gels was analyzed by confocal microscopy. This technique is used because it has a higher sharpness to stain the biopolymers and thus identify the spatial array structures of the biopolymers [67]. The presence of hemispherical particles (color blue) of sizes around $2-4 \mu \mathrm{m}$ (Figure $4 \mathrm{a}$ ) was observed. Furthermore, aggregated particles of different sizes (Figure 4b) were observed in the Greek-style yogurt (gray color), having aggregates smaller than $20 \mu \mathrm{m}$ (Figure 4c), allowing a more homogeneous distribution in the product. This indicates that the encapsulation system guarantees the protection of these bioactive compounds when incorporated into food. Geremias-Andrade et al. [68] developed and characterized polysaccharide and protein gels with curcumin using confocal microscopy. Moreover, whey protein complexes and gum arabic were observed using confocal microscopy to evaluate the morphology and stability of the oil droplets [69]. 


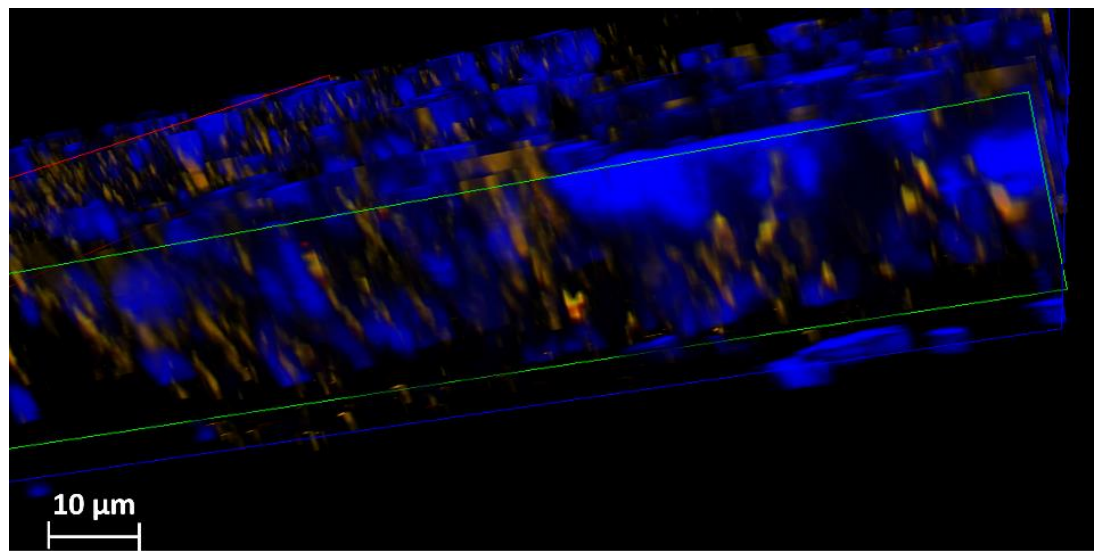

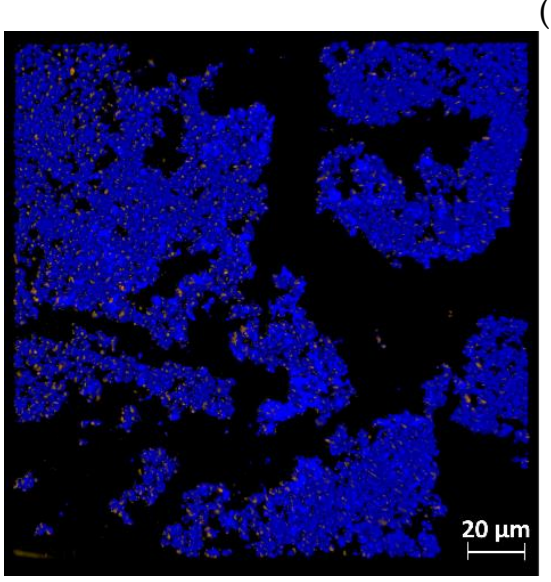

(b)

(a)

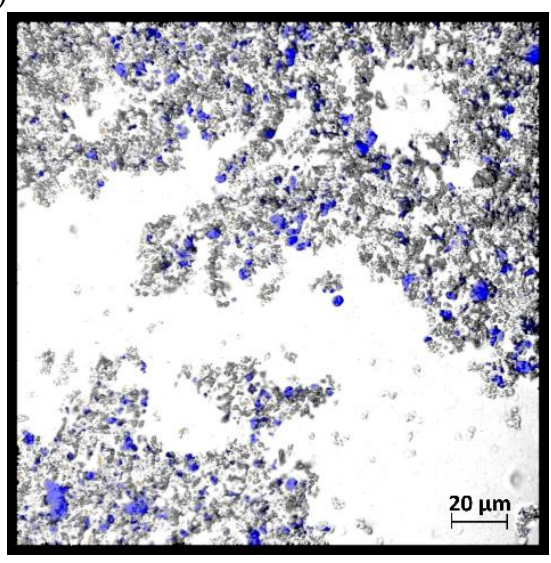

(c)

Figure 4. (a) Cross-section confocal microscopy of BPH-Gel, where BPH (yellow) is encapsulated in a gel (Blue). (b) Confocal microscopy of BPH-Gel (blue) encapsulating BPH (yellow). (c) Confocal microscopy of Greek-style yogurt (gray zone) with BPH-Gel, where BPH is encapsulated in a gel (blue).

\subsection{Sensory Evaluation of BPH-GEL-Yogurt and BPH-Ue-Yogurt}

One of the characteristics of protein hydrolysates and peptides is their bitter and astringent (dry mouth) perception [12,13], which makes them unpalatable, making it a challenge for their incorporation in food. These two descriptors were evaluated in $\mathrm{BPH}-$ Ue-yogurt and BPH-GEL-yogurt. In both, the addition of BPH was $2.3 \mathrm{~g}$ per serving $(125 \mathrm{~g})$. The bitter perception of BPH was mainly detected as opposed to astringency (Figure 5). In BPH-GEL-yogurt, both attributes' perception was significantly lower than in BPH-Ue-yogurt $(\mathrm{p}<0.05)$. The encapsulation process reduced $44 \%$ of the bitterness and $52 \%$ of the astringency of BPH in the BPH-GEL-yogurt. Some descriptors imparted by $\mathrm{BPH}$ were mushroom, liver, grass, umami, and butter in BPH-Ue-yogurt, in contrast to $\mathrm{BPH}-G e l-y o g u r t$, in which acidic, salty, and fatty notes were more predominant. Grass and mushrooms were less perceived. The liver, grass, mushroom, and salty notes of the $\mathrm{BPH}$ are possibly attributed to their extraction process, due to an excess of salts. In addition, one of the characteristics of legumes is their earthy flavor-cooked and smoked potatoes-which reduce their acceptance [70]. Despite many nutritional characteristics, the use of bioactive peptides is limited due to their bitterness and astringency. Recent research demonstrated that encapsulation is an alternative to improve food acceptance [27]. The extract of the bitter gourd fruit is rich in antioxidants and antidiabetic compounds. Its encapsulation reduced its bitterness and improved the stability of its bioactive compounds to use in food formulations [71]. 


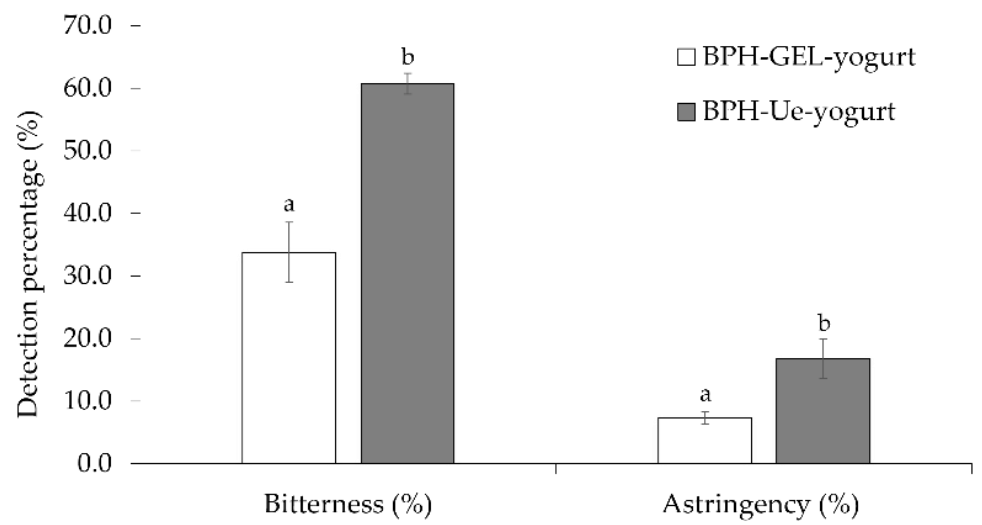

Figure 5. Bitterness and astringency of BPH-GEL-yogurt and BPH-Ue-yogurt. BPH-GEL-yogurt: Greek-style yogurt with BPH encapsulated in a gel; BPH-Ue-yogurt: Greek-style yogurt with unencapsulated BPH. Lowercase letters mean significantly different by the descriptor. $(p<0.05)$.

\subsection{Biological Potential}

Mojica and Gonzalez de Mejía [72] established the best processing conditions to generate BPH with in vitro antidiabetic potential (inhibition of $\alpha$-amylase, $\alpha$-glucosidase, and DPP-IV). Furthermore, Mojica et al. [11] evaluated the hypoglycemic capacity of the $\mathrm{BPH}$ in vivo, establishing the effective dose in rats to reduce $24.5 \%$ of the total area under the postprandial glucose curve $(200 \mathrm{mg} \mathrm{BPH} / \mathrm{kg} \mathrm{BW})$ and the equivalent dose in humans (2.3 $\mathrm{g} \mathrm{BPH}$ in a $70 \mathrm{~kg}$ person). Thus, this dose was considered for incorporation into BPH-GEL to be added to a serving of Greek-style yogurt (125 g). The BPH-GEL-yogurt and control yogurt were subjected to an in vitro simulated gastrointestinal digestion to evaluate the inhibition of $\alpha$-amylase and DPP-IV. The development of functional ingredients and their incorporation into food are an alternative to combat public health problems through food. Fermented dairy products are ideal for patients with type 2 diabetes [32]. Patients with glucose metabolism alterations could benefit from consuming functional foods that block $\alpha$-amylase and DPP-IV. The inhibition of $\alpha$-amylase may improve postprandial glucose in patients with type 2 diabetes [72]. Furthermore, DPP-IV inhibition may prevent incretin-like glucagon-like peptide-1 (GLP-1) and glucose-dependent insulinotropic peptide (GIP) degradation, potentiating insulin secretion and improving glucose homeostasis [73]. Several reports have been published related to foods as a source of bioactive compounds with antidiabetic potential, including oats [74], Capparis spinosa L [75], rice bran [76], and milk [77]. The in vitro simulated gastrointestinal analysis showed that in the stomach, no conclusive results were observed for $\alpha$-amylase and DPP-IV inhibition in the yogurt samples (Table 2).

Table 2. Biological potential of common bean protein hydrolysates. Inhibition of $\alpha$-amylase and DPP-IV of BPH-GEL-yogurt and control yogurt.

\begin{tabular}{cccc}
\hline \multirow{2}{*}{ Treatment } & Sample & $\begin{array}{l}\alpha \text {-Amylase } \\
\text { Inhibition }\end{array}$ & DPP-IV Inhibition \\
\cline { 2 - 4 } & & $\mathbf{( \% )}$ & $\mathbf{( \% )}$ \\
\hline \multirow{2}{*}{ BPH-GEL-yogurt } & Initial & $1.55 \pm 1.61^{\mathrm{aA}}$ & $\mathrm{ND}$ \\
& Stomach & $2.90 \pm 0.18^{\mathrm{aA}}$ & $\mathrm{ND}$ \\
& Intestine & $92.47 \pm 0.58^{\mathrm{bA}}$ & $75.24 \pm 1.43^{\mathrm{A}}$ \\
\hline \multirow{2}{*}{ Control yogurt } & Initial & $0.39 \pm 4.37^{\mathrm{aA}}$ & $\mathrm{ND}$ \\
& Stomach & $0.063 \pm 3.5^{\mathrm{aA}}$ & $\mathrm{ND}$ \\
& Intestine & $89.03 \pm 0.97^{\mathrm{bB}}$ & $69.13 \pm 0.74^{\mathrm{B}}$ \\
\hline
\end{tabular}

Sample Concentration: $1 \mathrm{mg}$ protein hydrolysate/mL. BPH-GEL-yogurt: Greek-style yogurt with BPH encapsulated in a gel; control yogurt: Greek-style yogurt without gel and BPH. Values are the mean of three replicates \pm standard deviation. Lowercase letters $(a, b)$ in the same treatment and capital letters $(A, B)$ by type of samples means significantly different $(p<0.05)$. 
This behavior could be because the BPH were encapsulated, and their functions could be limited. The inhibition occurred from the intestinal level for both enzymes (Table 2). Significant differences $(p<0.05)$ were observed after $3 \mathrm{~h}$ of simulated digestion in the $\alpha$-amylase inhibition between the BPH-GEL-yogurt $(92.47 \% \pm 0.58)$ and control yogurt $(89.03 \% \pm 0.97)$ at the intestinal level. Similar behavior was observed for DPP-IV inhibition. The highest inhibition was $75.24 \% \pm 1.43$ in the BPH-GEL-yogurt compared to $69.13 \% \pm 0.74$ in the control yogurt.

The increased inhibition of $\alpha$-amylase and DPP-IV could be due to the bioactive compounds being released from the matrix that protected them at the intestinal level, in addition to the possibility of synergy between the hydrolysates present in milk and BPH. Recently, in a clinical study, Ramos-Lopez et al. [3] reported that $5 \mathrm{~g}$ of BPH could reduce postprandial glucose in healthy humans in an oral glucose tolerance test. In this sense, two servings of BPH-GEL-yogurt per day could be an alternative to enhance the anti-diabetes effect in consumers.

\section{Conclusions}

Due to the interest in the consumption of functional foods, a gel based on gum arabic and whey protein concentrate was developed by complex coacervation and induced heat. The gel showed characteristics of a strong gel and low syneresis, similar characteristics to Greek-style yogurt. Common bean protein hydrolysates were incorporated into the gel as a protection system, homogeneously distributed throughout the Greek-style yogurt. This product developed with the gel enriched with the common bean protein hydrolysates maintained the texture and acidity characteristics of the control yogurt but with a higher protein content. The gel served as a protective barrier for the common bean protein hydrolysates, and sensory perceptions of bitterness and astringency were reduced. The off-flavors reduction could favor the acceptance of the consumption of this type of product. An increase in the inhibition of enzymes related to the treatment of type 2 diabetes was observed. Two servings per day of Greek-style yogurt with $2.3 \mathrm{~g}$ of encapsulated common bean protein hydrolysates could be an option for consumers seeking health-promoting alternatives. With the development of these gels, it may be feasible to evaluate the incorporation of other bioactive compounds to develop functional foods with better consumer acceptance in the dairy, meat, or bakery industries with health benefits for the control or prevention of non-communicable diseases.

\section{Patents}

MX/a/2019/014603. "Proceso de obtención de sistema de enmascaramiento de sabores amargos, astringencia o similares para uso en alimentos".

Author Contributions: Conceptualization, S.F.-M., L.M. and N.M.-H.; methodology, S.F.-M., L.M., H.E.-A. and N.M.-H.; formal analysis, S.F.-M. and N.M.-H.; investigation, S.F.-M. and N.M.-H.; writing-original draft preparation, S.F.-M., L.M., H.E.-A. and N.M.-H.; writing-review and editing, S.F.-M., L.M., H.E.-A. and N.M.-H.; supervision, N.M.-H.; project administration, L.M. and N.M.-H.; funding acquisition, L.M. All authors have read and agreed to the published version of the manuscript.

Funding: This research was funded by the "Consejo Nacional de Ciencia y Tecnología CONACYTMéxico, Problemas Nacionales 2016 grant number 2081".

Institutional Review Board Statement: Not applicable.

Informed Consent Statement: Not applicable.

Data Availability Statement: Data will be available upon request.

Acknowledgments: We would like to thank José Juvencio Castañeda Nava of Vegetal Biotechnology, CIATEJ, and Unidad Zapopan for the expertise provided for obtaining the CLSM micrographs.

Conflicts of Interest: The authors declare no conflict of interest. 


\begin{tabular}{|c|c|}
\hline GA & Gum arabic \\
\hline WPC & Whey protein concentrate \\
\hline $\mathrm{BPH}$ & Common bean protein hydrolysates \\
\hline W-GEL & Whey protein and gum arabic gel without common bean protein hydrolysates \\
\hline BPH-GEL & $\begin{array}{l}\text { Whey protein and gum arabic gel with encapsulated common } \\
\text { bean protein hydrolysates }\end{array}$ \\
\hline BPH-GEL-yogurt & $\begin{array}{l}\text { Greek-style yogurt with encapsulated common bean protein hydrolysates } \\
\text { in a whey protein and gum arabic gel. }\end{array}$ \\
\hline Control yogurt & $\begin{array}{l}\text { Greek-style yogurt without whey protein and gum arabic gel, and } \\
\text { common bean protein hydrolysates }\end{array}$ \\
\hline BPH-Ue-yogurt & Greek-style yogurt with unencapsulated common bean protein hydrolysates \\
\hline DPP-IV & Dipeptidyl peptidase- 4 \\
\hline FITC & Fluorescein isothiocyanate \\
\hline RBITC & Rhodamine isothiocyanate \\
\hline SGF & Simulated gastric fluid \\
\hline SIF & Simulated intestinal fluid \\
\hline
\end{tabular}

\section{References}

1. Birch, C.S.; Bonwick, G.A. Ensuring the future of functional foods. Int. J. Food Sci. Technol. 2019, 54, 1467-1485. [CrossRef]

2. Xiong, K.; Zhou, L.; Wang, J.; Ma, A.; Fang, D.; Xiong, L.; Sun, Q. Construction of food-grade pH-sensitive nanoparticles for delivering functional food ingredients. Trends Food Sci. Technol. 2020, 96, 102-113. [CrossRef]

3. Ramos-Lopez, A.; Mojica, L.; Gomez-Ojeda, A.; Macias-Cervantes, M.; Luevano-Contreras, C. Acute Effect of Black Bean (Phaseolus vulgaris L.) Hydrolyzed Protein on Glucose Levels in Adults with Prediabetes and Normal Glucose Tolerance. Curr. Dev. Nutr. 2020, 4, 458. [CrossRef]

4. Boye, J.; Zare, F.; Pletch, A. Pulse proteins: Processing, characterization, functional properties and applications in food and feed. Food Res. Int. 2010, 43, 414-431. [CrossRef]

5. Tosh, S.M.; Yada, S. Dietary fibres in pulse seeds and fractions: Characterization, functional attributes, and applications. Food Res. Int. 2010, 43, 450-460. [CrossRef]

6. Luna-Vital, D.A.; Mojica, L.; de Mejía, E.G.; Mendoza, S.; Loarca-Piña, G. Biological potential of protein hydrolysates and peptides from common bean (Phaseolus vulgaris L.): A review. Food Res. Int. 2015, 76, 39-50. [CrossRef]

7. Mojica, L.; de Mejía, E.G. Characterization and comparison of protein and peptide profiles and their biological activities of improved common bean cultivars (Phaseolus vulgaris L.) from Mexico and Brazil. Plant Foods Hum. Nutr. 2015, 70, 105-112. [CrossRef]

8. de Souza Rocha, T.; Hernandez, L.M.R.; Mojica, L.; Johnson, M.H.; Chang, Y.K.; de Mejia, E.G. Germination of Phaseolus vulgaris and alcalase hydrolysis of its proteins produced bioactive peptides capable of improving markers related to type-2 diabetes in vitro. Food Res. Int. 2015, 76, 150-159. [CrossRef]

9. Mojica, L.; Chen, K.; de Mejía, E.G. Impact of commercial precooking of common bean (Phaseolus vulgaris) on the generation of peptides, after pepsin-pancreatin hydrolysis, capable to inhibit dipeptidyl peptidase-IV. J. Food Sci. 2015, 80, H188-H198. [CrossRef]

10. Mojica, L.; Luna-Vital, D.A.; de Mejia, E.G. Black bean peptides inhibit glucose uptake in Caco-2 adenocarcinoma cells by blocking the expression and translocation pathway of glucose transporters. Toxicol. Rep. 2018, 5, 552-560. [CrossRef]

11. Mojica, L.; de Mejia, E.G.; Granados-Silvestre, M.Á.; Menjivar, M. Evaluation of the hypoglycemic potential of a black bean hydrolyzed protein isolate and its pure peptides using in silico, in vitro and in vivo approaches. J. Funct. Foods 2017, 31, 274-286. [CrossRef]

12. Li-Chan, E.C. Bioactive peptides and protein hydrolysates: Research trends and challenges for application as nutraceuticals and functional food ingredients. Curr. Opin. Food Sci. 2015, 1, 28-37. [CrossRef]

13. Udenigwe, C.C.; Fogliano, V. Food matrix interaction and bioavailability of bioactive peptides: Two faces of the same coin? J. Funct. Foods 2017, 35, 9-12. [CrossRef]

14. Liu, L.; Li, S.; Zheng, J.; Bu, T.; He, G.; Wu, J. Safety considerations on food protein-derived bioactive peptides. Trends Food Sci. Technol. 2020, 96, 199-207. [CrossRef]

15. Van Lancker, F.; Adams, A.; De Kimpe, N. Chemical modifications of peptides and their impact on food properties. Chem. Rev. 2011, 111, 7876-7903. [CrossRef] [PubMed]

16. Zhu, J.; Huang, Q. Nanoencapsulation of functional food ingredients. Adv. Food Nutr. Res. 2019, 88, 129-165. [CrossRef]

17. Bazana, M.T.; Codevilla, C.F.; de Menezes, C.R. Nanoencapsulation of bioactive compounds: Challenges and perspectives. Curr. Opin. Food Sci. 2019, 26, 47-56. [CrossRef]

18. Mohan, A.; Rajendran, S.R.; He, Q.S.; Bazinet, L.; Udenigwe, C.C. Encapsulation of food protein hydrolysates and peptides: A review. RSC Adv. 2015, 5, 79270-79278. [CrossRef] 
19. Wen, P.; Zong, M.-H.; Linhardt, R.J.; Feng, K.; Wu, H. Electrospinning: A novel nano-encapsulation approach for bioactive compounds. Trends Food Sci. Technol. 2017, 70, 56-68. [CrossRef]

20. McClements, D.J. Application as functional ingredients to control lipid digestion and bioavailability. Food Hydrocoll. 2021, 111, 106404. [CrossRef]

21. Nazir, A.; Asghar, A.; Maan, A.A. Food gels: Gelling process and new applications. In Advances in Food Rheology and Its Applications; Elsevier: Amsterdam, The Netherlands, 2017; pp. 335-353.

22. Azarikia, F.; Wu, B.-C.; Abbasi, S.; McClements, D.J. Stabilization of biopolymer microgels formed by electrostatic complexation: Influence of enzyme (laccase) cross-linking on $\mathrm{pH}$, thermal, and mechanical stability. Food Res. Int. 2015, 78, 18-26. [CrossRef]

23. Warnakulasuriya, S.N.; Nickerson, M.T. Review on plant protein-polysaccharide complex coacervation, and the functionality and applicability of formed complexes. J. Sci. Food Agric. 2018, 98, 5559-5571. [CrossRef]

24. Totosaus, A.; Montejano, J.G.; Salazar, J.A.; Guerrero, I. A review of physical and chemical protein-gel induction. Int. J. Food Sci. Technol. 2002, 37, 589-601. [CrossRef]

25. Dias, D.R.; Botrel, D.A.; Fernandes, R.V.D.B.; Borges, S.V. Encapsulation as a tool for bioprocessing of functional foods. Curr. Opin. Food Sci. 2017, 13, 31-37. [CrossRef]

26. Kuhn, K.R.; e Silva, F.G.D.; Netto, F.M.; da Cunha, R.L. Production of whey protein isolate-gellan microbeads for encapsulation and release of flaxseed bioactive compounds. J. Food Eng. 2019, 247, 104-114. [CrossRef]

27. Newman, J.; O'Riordan, D.; Jacquier, J.; O'Sullivan, M. Masking of bitterness in dairy protein hydrolysates: Comparison of an electronic tongue and a trained sensory panel as means of directing the masking strategy. LWT-Food Sci. Technol. 2015, 63, 751-757. [CrossRef]

28. Silva, D.; Favaro-Trindade, C.; Rocha, G.; Thomazini, M. Microencapsulation of lycopene by gelatin-pectin complex coacervation. J. Food Process. Preserv. 2012, 36, 185-190. [CrossRef]

29. Breternitz, N.R.; Bolini, H.M.A.; Hubinger, M.D. Sensory acceptance evaluation of a new food flavoring produced by microencapsulation of a mussel (Perna perna) protein hydrolysate. LWT-Food Sci. Technol. 2017, 83, 141-149. [CrossRef]

30. Mendanha, D.V.; Ortiz, S.E.M.; Favaro-Trindade, C.S.; Mauri, A.; Monterrey-Quintero, E.S.; Thomazini, M. Microencapsulation of casein hydrolysate by complex coacervation with SPI/pectin. Food Res. Int. 2009, 42, 1099-1104. [CrossRef]

31. Ley, S.H.; Hamdy, O.; Mohan, V.; Hu, F.B. Prevention and management of type 2 diabetes: Dietary components and nutritional strategies. Lancet 2014, 383, 1999-2007. [CrossRef]

32. American Diabetes Association. Available online: www.diabetes.org/ (accessed on 9 August 2021).

33. Gyawali, R.; Ibrahim, S.A. Effects of hydrocolloids and processing conditions on acid whey production with reference to Greek yogurt. Trends Food Sci. Technol. 2016, 56, 61-76. [CrossRef]

34. Jørgensen, C.E.; Abrahamsen, R.K.; Rukke, E.-O.; Hoffmann, T.K.; Johansen, A.-G.; Skeie, S.B. Processing of high-protein yoghurt-A review. Int. Dairy J. 2019, 88, 42-59. [CrossRef]

35. Godoy-García, L.; Abadía-García, L.; Cruz-Aldaco, K.; Castaño-Tostado, E.; Murúa-Pagola, B.; Amaya-Llano, S.L. Addition of glycomacropeptide as fat replacer in sugar-reduced Greek-style yoghurt. Int. J. Dairy Technol. 2020, 73, 718-725. [CrossRef]

36. Eleya, M.O.; Turgeon, S. The effects of $\mathrm{pH}$ on the rheology of $\beta$-lactoglobulin/ $\mathrm{k}$-carrageenan mixed gels. Food Hydrocoll. 2000, 14, 245-251. [CrossRef]

37. Rodríguez-Rodríguez, R.; Espinosa-Andrews, H.; Morales-Hernández, N.; Lobato-Calleros, C.; Vernon-Carter, E.J. Mesquite gum/chitosan insoluble complexes: Relationship between the water state and viscoelastic properties. J. Dispers. Sci. Technol. 2018. [CrossRef]

38. Qin, X.S.; Luo, S.Z.; Cai, J.; Zhong, X.Y.; Jiang, S.T.; Zhao, Y.Y.; Zheng, Z. Transglutaminase-induced gelation properties of soy protein isolate and wheat gluten mixtures with high intensity ultrasonic pretreatment. Ultrason. Sonochem. 2016, 31, 590-597. [CrossRef]

39. Banerjee, S.; Bhattacharya, S. Compressive textural attributes, opacity and syneresis of gels prepared from gellan, agar and their mixtures. J. Food Eng. 2011, 102, 287-292. [CrossRef]

40. Li, F.; Kong, X.; Zhang, C.; Hua, Y. Gelation behaviour and rheological properties of acid-induced soy protein-stabilized emulsion gels. Food Hydrocoll. 2012, 29, 347-355. [CrossRef]

41. Crispín-Isidro, G.; Lobato-Calleros, C.; Espinosa-Andrews, H.; Alvarez-Ramirez, J.; Vernon-Carter, E. Effect of inulin and agave fructans addition on the rheological, microstructural and sensory properties of reduced-fat stirred yogurt. LWT-Food Sci. Technol. 2015, 62, 438-444. [CrossRef]

42. NOM-243-SSA1. Leche, Fórmula Láctea, Producto Lácteo Combinado y Derivados Lácteos—Disposiciones y Especificaciones Sanitarias-Métodos de Prueba. 2010. Available online: http://dof.gob.mx/nota_detalle.php?codigo=5160755\&fecha=27 /09/2010\#: \{\}:text=1.1\%20Esta\%20Norma\%20Oficial\%20Mexicana,combinado\%20y\%20los\%20derivados $\% 201 \%$ C3\%A1cteos (accessed on 18 October 2021).

43. Schmitt, C.; Sanchez, C.; Lamprecht, A.; Renard, D.; Lehr, C.-M.; de Kruif, C.G.; Hardy, J. Study of $\beta$-lactoglobulin/acacia gum complex coacervation by diffusing-wave spectroscopy and confocal scanning laser microscopy. Colloids Surf. B Biointerfaces 2001, 20, 267-280. [CrossRef]

44. ISO (International Organization for Standarization). Sensory analysis-General guidance for the selection, training and monitoring of assessors. In Part 2: Expert Sensory Assessors; ISO 8586-2: Geneva, Switzerland, 2008. 
45. Sanguansri, L.; Day, L.; Shen, Z.; Fagan, P.; Weerakkody, R.; Cheng, L.J.; Rusli, J.; Augustin, M.A. Encapsulation of mixtures of tuna oil, tributyrin and resveratrol in a spray dried powder formulation. Food Funct. 2013, 4, 1794-1802. [CrossRef] [PubMed]

46. Kusano, R.; Ogawa, S.; Matsuo, Y.; Tanaka, T.; Yazaki, Y.; Kouno, I. $\alpha$-Amylase and lipase inhibitory activity and structural characterization of acacia bark proanthocyanidins. J. Nat. Prod. 2011, 74, 119-128. [CrossRef] [PubMed]

47. Hsieh-Lo, M.; Castillo-Herrera, G.; Mojica, L. Black bean anthocyanin-rich extract from supercritical and pressurized extraction increased in vitro antidiabetic potential, while having similar storage stability. Foods 2020, 9, 655. [CrossRef] [PubMed]

48. Chung, C.; McClements, D.J. Structure-function relationships in food emulsions: Improving food quality and sensory perception. Food Struct. 2014, 1, 106-126. [CrossRef]

49. Liu, F.; Tang, C.-H. Emulsifying properties of soy protein nanoparticles: Influence of the protein concentration and/or emulsification process. J. Agric. Food Chem. 2014, 62, 2644-2654. [CrossRef]

50. Mao, R.; Tang, J.; Swanson, B. Water holding capacity and microstructure of gellan gels. Carbohydr. Polym. 2001, 46, 365-371. [CrossRef]

51. Espinosa-Andrews, H.; Sandoval-Castilla, O.; Vázquez-Torres, H.; Vernon-Carter, E.J.; Lobato-Calleros, C. Determination of the gum Arabic-chitosan interactions by Fourier Transform Infrared Spectroscopy and characterization of the microstructure and rheological features of their coacervates. Carbohydr. Polym. 2010, 79, 541-546. [CrossRef]

52. Weinbreck, F.; Minor, M.; De Kruif, C. Microencapsulation of oils using whey protein/gum arabic coacervates. J. Microencapsul. 2004, 21, 667-679. [CrossRef]

53. Rojas-Moreno, S.; Cardenas-Bailon, F.; Osorio-Revilla, G.; Gallardo-Velazquez, T.; Proal-Najera, J. Effects of complex coacervationspray drying and conventional spray drying on the quality of microencapsulated orange essential oil. J. Food Meas. Charact. 2018, 12, 650-660. [CrossRef]

54. Bastos, L.P.H.; Vicente, J.; dos Santos, C.H.C.; de Garvalho, M.G.; Garcia-Rojas, E.E. Encapsulation of black pepper (Piper nigrum L.) essential oil with gelatin and sodium alginate by complex coacervation. Food Hydrocoll. 2020, 102, 105605. [CrossRef]

55. Rutz, J.K.; Borges, C.D.; Zambiazi, R.C.; Crizel-Cardozo, M.M.; Kuck, L.S.; Noreña, C.P. Microencapsulation of palm oil by complex coacervation for application in food systems. Food Chem. 2017, 220, 59-66. [CrossRef] [PubMed]

56. Costa, M.F.; Pimentel, T.C.; Guimaraes, J.T.; Balthazar, C.F.; Rocha, R.S.; Cavalcanti, R.N.; Esmerino, E.A.; Freitas, M.Q.; Raices, R.S.; Silva, M.C. Impact of prebiotics on the rheological characteristics and volatile compounds of Greek yogurt. LWT 2019, 105, 371-376. [CrossRef]

57. Pinto, S.S.; Cavalcante, B.D.; Verruck, S.; Alves, L.F.; Prudêncio, E.S.; Amboni, R.D. Effect of the incorporation of Bifidobacterium BB-12 microencapsulated with sweet whey and inulin on the properties of Greek-style yogurt. J. Food Sci. Technol. 2017, 54, 2804-2813. [CrossRef] [PubMed]

58. Desai, N.; Shepard, L.; Drake, M. Sensory properties and drivers of liking for Greek yogurts. J. Dairy Sci. 2013, 96, 7454-7466. [CrossRef] [PubMed]

59. Uduwerella, G.; Chandrapala, J.; Vasiljevic, T. Preconcentration of yoghurt base by ultrafiltration for reduction in acid whey generation during Greek yoghurt manufacturing. Int. J. Dairy Technol. 2018, 71, 71-80. [CrossRef]

60. Uduwerella, G.; Chandrapala, J.; Vasiljevic, T. Minimising generation of acid whey during Greek yoghurt manufacturing. J. Dairy Res. 2017, 84, 346-354. [CrossRef] [PubMed]

61. Villeda, C.M. Elaboración de Yogur Estilo Griego con Diferentes Porcentajes de ATECAL, Leche en Polvo y Horas de Desuerado. Bachelor's Thesis, Escuela Agricola Panamericana, Zamorano, Tegucigalpa, Honduras, 2015.

62. NOM-181-SCFI/SAGARPA. Yogurt-Denominación, Especificaciones Fisicoquímicas y Microbiológicas, Información Comercial y Métodos de Prueba. 2018. Available online: https://dof.gob.mx/nota_detalle.php?codigo=5549317\&fecha=31/01/2019 (accessed on 18 October 2021).

63. Fernandez, M.A.; Picard-Deland, É.; Barz, M.L.; Daniel, N.; Marette, A. Yogurt and Health. In Fermented Foods in Health and Disease Prevention; Elsevier: Amsterdam, The Netherlands, 2016; pp. 305-338.

64. Rinaldoni, A.N.; Campderrós, M.E.; Padilla, A.P. Physico-chemical and sensory properties of yogurt from ultrafiltreted soy milk concentrate added with inulin. LWT-Food Sci. Technol. 2012, 45, 142-147. [CrossRef]

65. Gilbert, A.; Turgeon, S.L. Studying stirred yogurt microstructure and its correlation to physical properties: A review. Food Hydrocoll. 2021, 106970. [CrossRef]

66. Oliveira, M.; Sodini, I.; Remeuf, F.; Corrieu, G. Effect of milk supplementation and culture composition on acidification, textural properties and microbiological stability of fermented milks containing probiotic bacteria. Int. Dairy J. 2001, 11, 935-942. [CrossRef]

67. Moschakis, T.; Biliaderis, C.G. Biopolymer-based coacervates: Structures, functionality and applications in food products. Curr. Opin. Colloid Interface Sci. 2017, 28, 96-109. [CrossRef]

68. Geremias-Andrade, I.M.; Souki, N.P.; Moraes, I.C.; Pinho, S.C. Rheological and mechanical characterization of curcumin-loaded emulsion-filled gels produced with whey protein isolate and xanthan gum. LWT 2017, 86, 166-173. [CrossRef]

69. Estrada-Fernández, A.; Román-Guerrero, A.; Jiménez-Alvarado, R.; Lobato-Calleros, C.; Alvarez-Ramirez, J.; Vernon-Carter, E. Stabilization of oil-in-water-in-oil (O1/W/O2) Pickering double emulsions by soluble and insoluble whey protein concentrategum Arabic complexes used as inner and outer interfaces. J. Food Eng. 2018, 221, 35-44. [CrossRef]

70. Mishra, P.K.; Tripathi, J.; Gupta, S.; Variyar, P.S. Effect of cooking on aroma profile of red kidney beans (Phaseolus vulgaris) and correlation with sensory quality. Food Chem. 2017, 215, 401-409. [CrossRef] [PubMed] 
71. Erami, S.R.; Amiri, Z.R.; Jafari, S.M. Nanoliposomal encapsulation of Bitter Gourd (Momordica charantia) fruit extract as a rich source of health-promoting bioactive compounds. LWT 2019, 116, 108581. [CrossRef]

72. Mojica, L.; De Mejía, E.G. Optimization of enzymatic production of anti-diabetic peptides from black bean (Phaseolus vulgaris L.) proteins, their characterization and biological potential. Food Funct. 2016, 7, 713-727. [CrossRef]

73. Moreno-Valdespino, C.A.; Luna-Vital, D.; Camacho-Ruiz, R.M.; Mojica, L. Bioactive proteins and phytochemicals from legumes: Mechanisms of action preventing obesity and type-2 diabetes. Food Res. Int. 2020, 130, 108905. [CrossRef]

74. Wang, F.; Zhang, Y.; Yu, T.; He, J.; Cui, J.; Wang, J.; Cheng, X.; Fan, J. Oat globulin peptides regulate antidiabetic drug targets and glucose transporters in Caco-2 cells. J. Funct. Foods 2018, 42, 12-20. [CrossRef]

75. Mollica, A.; Zengin, G.; Locatelli, M.; Stefanucci, A.; Mocan, A.; Macedonio, G.; Carradori, S.; Onaolapo, O.; Onaolapo, A.; Adegoke, J. Anti-diabetic and anti-hyperlipidemic properties of Capparis spinosa L.: In vivo and in vitro evaluation of its nutraceutical potential. J. Funct. Foods 2017, 35, 32-42. [CrossRef]

76. Hatanaka, T.; Inoue, Y.; Arima, J.; Kumagai, Y.; Usuki, H.; Kawakami, K.; Kimura, M.; Mukaihara, T. Production of dipeptidyl peptidase IV inhibitory peptides from defatted rice bran. Food Chem. 2012, 134, 797-802. [CrossRef]

77. Shori, A.B. Proteolytic activity, antioxidant, and $\alpha$-Amylase inhibitory activity of yogurt enriched with coriander and cumin seeds. LWT 2020, 133, 109912. [CrossRef] 